\title{
Water use efficiency in four irrigation regimes in bulb onion production in the Alto Chicamocha Irrigation District
}

\section{Eficiencia en el uso del agua en cuatro láminas de riego sobre la producción de cebolla de bulbo para el Distrito de Riego Alto Chicamocha}
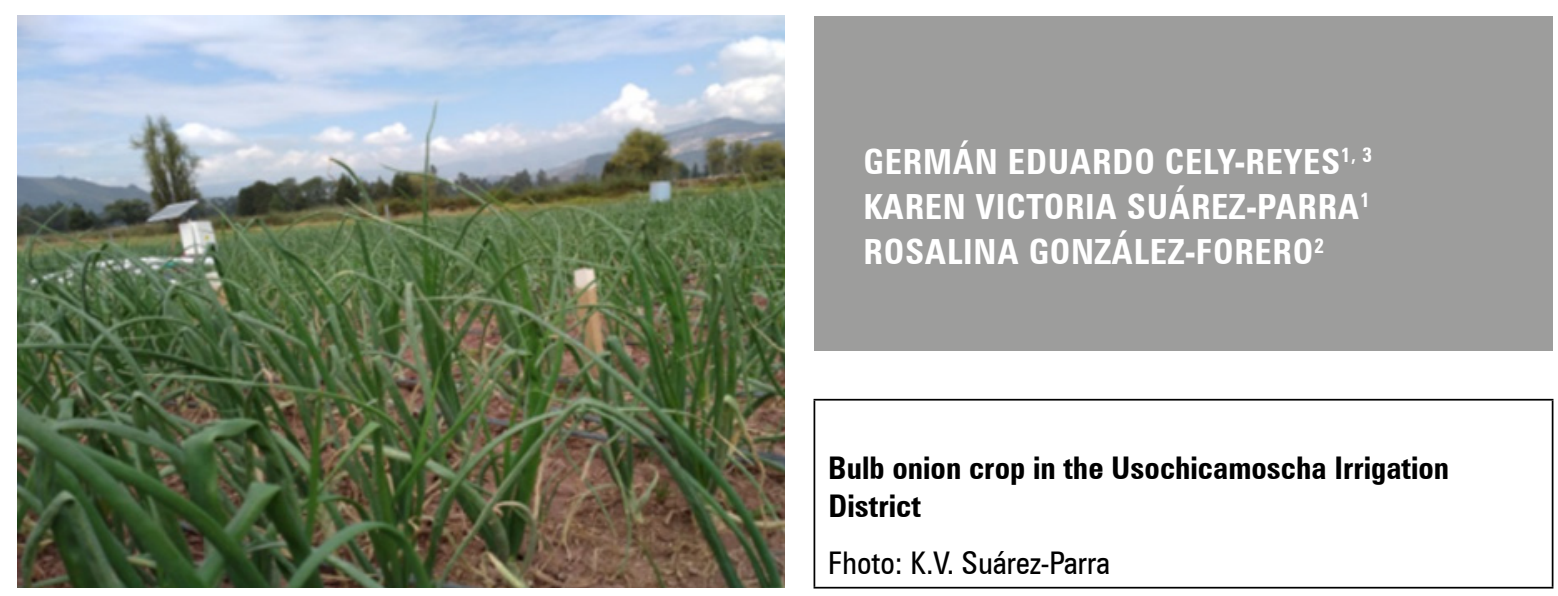

\section{ABSTRACT}

The bulb onion is one of the most important agricultural products in Colombia. The productive conditions of the Riego del Alto Chicamocha (Boyaca) district are a regional and national benchmark for this market. The objective of this research was to evaluate four irrigation regimes in terms of production and irrigation water efficiency in bulb onion crops. This trial was in the municipality of Nobsa, village of Dicho (Boyaca). A completely randomized design with four treatments was used: irrigation regime with 150\% evapotranspiration (Evt); moisture-based irrigation regime, detected with soil moisture sensors; irrigation regime with 100\% Evt; irrigation regime with $60 \%$ Evt, along with four repetitions. Starting three weeks after transplant and for 11 weeks (77 days), the polar diameter $(\mathrm{cm})$, equatorial diameter $(\mathrm{cm})$, root length $(\mathrm{cm})$, leaf length $(\mathrm{cm})$, SPAD units, stomatal conductance and irrigation water use efficiency were determined. The irrigation regime with 100\% Evt had the best performance in terms of the polar and equatorial diameters and the root and leaf lengths, which were reflected in the fresh weight at harvest. The irrigation regime with soil moisture values obtained from remote sensors, with lower amounts of applied water, had better values for the transformation of water to fresh mass, with $13.64 \mathrm{~kg} \mathrm{~mm}^{-1}$.

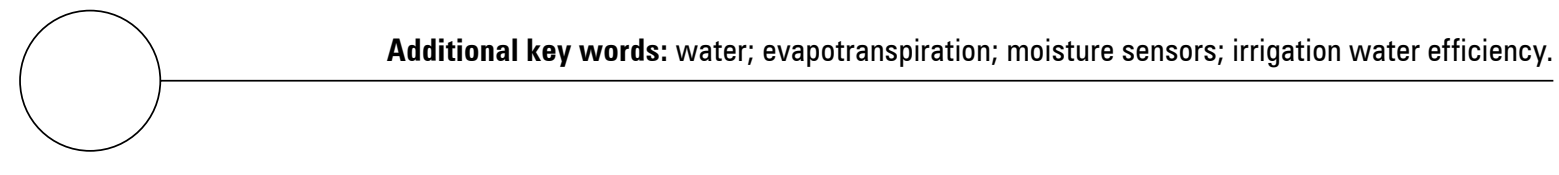

1 Universidad Pedagógica y Tecnológica de Colombia, Grupo de Investigación GIPSO; Universidad de La Salle, Doctorado en AgroCiencias, Tunja (Colombia). ORCID Cely-Reyes, G.E.: 0000-0001-6312-3575; ORCID Suárez-Parra, K.V.: 0000-0003-2736-9070

2 Universidad de La Salle, Facultad de Ingeniería, Bogota (Colombia). ORCID González-Forero, R.: 0000-0002-5860-657X

3 Corresponding author. german.cely@uptc.edu.co 


\section{RESUMEN}

La cebolla de bulbo es uno de los productos agrícolas más importantes en Colombia; las condiciones productivas del distrito de Riego del Alto Chicamocha (Boyacá) son un referente regional y nacional para dicho mercado. El objetivo de ésta investigación fue la evaluación de cuatro láminas de riego en términos de producción y eficiencia del agua de riego sobre la producción y eficiencia del agua para riego en el cultivo de cebolla de bulbo. El ensayo se ubicó en el municipio de Nobsa, vereda Dichó (Boyacá). Se empleó un diseño completamente al azar con cuatro tratamientos; lámina de riego al 150\% de la evapotranspiración (Evt); lámina de riego basada en humedad detectada por sensores de humedad del suelo; lámina de riego al 100\% de la Evt, y lámina de riego al 60\% de la Evt con cuatro repeticiones. A partir de la tercera semana del trasplante, se inició el seguimiento por 11 semanas (77 días), se evaluó el diámetro polar $(\mathrm{cm})$, diámetro ecuatorial $(\mathrm{cm})$, longitud de raíz $(\mathrm{cm})$, longitud de hojas $(\mathrm{cm})$, unidades SPAD, conductancia estomática y eficiencia en el uso del agua de riego. La aplicación de la lámina de riego supliendo el 100\% de la Evt mostró el mejor rendimiento en términos de diámetro tanto polar como ecuatorial, longitud de raíz y de hoja, los cuales se vieron reflejados en el peso fresco a cosecha. Las aplicaciones de láminas de agua basados en valores de humedad de suelo obtenidos a partir de sensores remotos, con menores cantidades de agua aplicada presenta mejores valores de transformación de agua en masa fresca con 13,64 $\mathrm{kg} \mathrm{mm}^{-1}$.

Palabras clave adicionales: agua; evapotranspiración; sensores de humedad; eficiencia de agua de riego.

Received for publication: 20-10-2020 Accepted for publication: 23-11-2020

INTRODUCTION

The main objective of agriculture is to satisfy the food needs of humans, which is linked to the proper use of irrigation water, the main input for production (Gómez et al., 2015). Agricultural production processes use $75 \%$ of available water, so proper use and conservation should be a priority, maintaining a productive and natural balance in hydrographic basins of high environmental interest (Ríos et al., 2016). Because climate change has led to water scarcity, agricultural production has resorted to new production strategies and irrigation management, reducing the amount of water applied without affecting yield, which include the modernization of irrigation systems, intermittent irrigation programs and even the use of new varieties resistant to water stress (Sánchez et al., 2017; Mai et al., 2019).

Irrigation is a tool that improves productivity in agricultural systems, maintaining water in crops for maximum expression. The main concern in irrigation is when and how much water to use, which is determined with irrigation planning (Caicedo et al., 2015). The use of water in irrigated agriculture depends on multiple factors in the soil, climate, management and environment; the efficient use of water is reflected in productivity (Bonet et al., 2010; Wakchaure et al., 2018).
Water productivity is a term coined by Kijne et al. (2003), a measurement in systems for the conversion of water to food, achieving efficiency when less water is applied and obtaining greater production (Ríos-Flores et al., 2015). Current resource management practices use extensive modifications depending on the crop type that is irrigated (Bolaños et al., 2017). The bulb onion requires frequent irrigation, is highly sensitive to water stress and generates high water losses because of inefficient and excessive irrigation (Channagoudra et al., 2009; Haller and Jonsson, 2020).

Different methods are used to determine the amount of water to apply. Two reliable methods are evapotranspiration value management (Evt) and use of soil moisture sensors. Both methods require an evaluation of climate and edaphic factors, giving the calculation greater precision (Enciso et al., 2009; Minhas et al., 2020).

In Colombia, bulb onion production is distributed in various geographical areas of the country. The Department of Boyaca stands out as one of the main production areas, with more than $162,400 \mathrm{t}$, providing $54 \%$ of the total domestic production, and the upper Chicamocha irrigation district is a center of onion 
cultivation, with a planted area that reaches 525 ha in each productive cycle. Therefore, the objective of this research was to analyze the physiological and productive development of bulb onions subjected to four irrigation regimes calculated with the climatic conditions (Evt) and soil moisture sensors in the Irrigation and Drainage District of Alto Chicamocha and Firavitoba- USOCHICAMOCHA Boyaca. Despite the adequate irrigation infrastructure, technical capacities have not yet been developed for the efficient use of water in agricultural production.

\section{MATERIALS AND METHODS}

This study was carried out from January to April, 2020 in a bulb onion crop (Allium cepa L.) established on the San Rafael Farm $\left(5.787108^{\circ} \mathrm{N}, 72.973650^{\circ} \mathrm{W}\right.$; 2,593 $\mathrm{m}$ a.s.1.), in the village of Dicho, Nobsa municipality, Boyaca Department, within the Irrigation and Drainage district of Alto Chicamocha and FiravitobaUsochicamocha. A completely randomized design with four treatments and four repetitions was used. This study had an experimental area of $600 \mathrm{~m}^{2}$, divided into 16 plots of $37.5 \mathrm{~m}^{2}$.

The irrigation regimes were: 1) $150 \%$ evapotranspiration $(150 \%$ Evt, determined with the Making equation); 2) moisture-based irrigation regime, detected with soil moisture sensors (Vegetronix moisture sensors [VH400 model, Vegetronix, Riverton, UT] that evaluated the validity of the recorded data and measured the amount of water applied. This sensor was selected because it had the best performance according to the previous calibration process); 3 ) irrigation regime with $100 \%$ evapotranspiration (100\% Evt), and 4 ) irrigation regime with $60 \%$ evapotranspiration (60\% Evt).

A drip irrigation system was used, with self-compensated drippers, $1.0 \mathrm{~L} \mathrm{~h}^{-1}$ discharge flow, and 20 $\mathrm{cm}$ between drippers. Each irrigation sector had an electronic regulation valve for the automated management of the irrigation times in each treatment. Two irrigation times per day were used: one in the morning with $50 \%$ of the total daily regime and the remaining $50 \%$ in the afternoon.

The physiological monitoring of the onion crop started with the installation of the irrigation system (week 3 of the transplant) and lasted until $77 \mathrm{~d}$ after transplant (11 weeks), including the variables: equatorial diameter $(\mathrm{cm})$, polar diameter $(\mathrm{cm})$, leaf length $(\mathrm{cm})$, stomatal conductance (SC-1 Leaf Porometer, Meter Group), and Relative Chlorophyll Index (CRI) or SPAD units (Soil Plant Analysis Development, Konica Minolta). At harvest, the total fresh weight for each treatment was determined.

The evapotranspiration (Evt) was determined with the equation proposed by Making. The climatic data for the Evt determination were obtained with a climatic station installed at the test site. Additionally, the irrigation water efficiency (IWUE) was determined using the formula proposed by (Kijne et al., 2003) (1):

$$
I W U E=\frac{Y a}{I W}
$$

where $Y a$ was crop yield in $\mathrm{kg} \mathrm{ha}^{-1}$, and $I W$ was total amount of applied water ( $\mathrm{mm}$ ).

Finally, the values obtained with the physiological monitoring of the onions were processed in the free version of Infostat (Infostat, 2020), which used analysis of variance (ANOVA) and the Tukey multiple comparison analysis with a reliability of $95 \%$.

\section{RESULTS AND DISCUSSION}

Table 1 shows the total supplied water $(\mathrm{mm})$ for each treatment and the total onion production $\left(\mathrm{kg} \mathrm{ha}^{-1}\right)$ and IWUE $\left(\mathrm{kg} \mathrm{mm}^{-1}\right)$. The precipitation during the study was $212.10 \mathrm{~mm}$, which aided establishment of the crop through direct dependence on water supplied through irrigation. Therefore, the precipitation value was not taken into account for the production analysis.

\section{Table 1. Production values, total water supplied and irriga-} tion water efficiency IWUE.

\begin{tabular}{|l|c|c|c|}
\hline Treatment & $\begin{array}{c}\text { Production } \\
\left(\mathrm{kg} \mathrm{ha}^{-1}\right)\end{array}$ & $\begin{array}{c}\text { Total water } \\
(\mathrm{mm})\end{array}$ & $\begin{array}{c}\text { IWUE } \\
\left(\mathrm{kg} \mathrm{mm}^{-1}\right)\end{array}$ \\
\hline $150 \%$ Evt & $46,130.92 \mathrm{c}$ & 11,574 & 3.98 \\
\hline Humidity sensor & $53,819.41 \mathrm{~b}$ & 3,943 & 13.64 \\
\hline $100 \%$ Evt & $64,583.3 \mathrm{a}$ & 7,716 & 8.37 \\
\hline $60 \%$ Evt & $34,308.3 \mathrm{~d}$ & 4,630 & 7.41 \\
\hline
\end{tabular}

Evt: evapotranspiration. Means with different letters indicate significant difference according to Tukey's test $(P \leq 0.05)$.

The results in table 1 indicate that the treatment with the highest production was 100\% Evt (64583.3 $\mathrm{kg} \mathrm{ha}^{-1}$ ), followed by the moisture sensors (with a 
regime based on the moisture recorded by the sensors), $150 \%$ Evt, and finally $60 \%$ Evt, with the lowest production. When supplying $100 \%$ of the calculated Evt, higher production was obtained; however, water consumption was $51.1 \%$ greater than with the moisture sensors $(3943 \mathrm{~mm})$, with a regime calculated using moisture sensors, which had the best IWUE index: $13.64 \mathrm{~kg} \mathrm{~mm}^{-1}$.

These results are contrary to those reported by Perez and Knox (2014), who observed higher IWUE efficiencies with reduced water applications because the availability of water during onion growth is not only determinant for bulb size but also influences storage time. A water restriction reduces yield and produces bulbs with a lower water content because of reduced expansion in the division of foliar cells, with delayed bulbification, leading to smaller diameters, lower weights, less volume and a larger breathable area. Smaller water regimes generate lower respiration rates and are positively correlated with physiological activity, which is generally higher than with greater regimes (Assuero et al., 2007; Rattin et al., 2011; Geries et al., 2020; Liu et al., 2020).

Physiologically, a water reduction negatively affects functions, such as photosynthesis, respiration, metabolic and anatomical reactions, growth, reproduction, absorption of mineral nutrients, transport of assimilates and production, by intervening in all biological processes. As a response to water stress, plants stop developing, with leaf wilting and a reduction in water potential, stomatal conductance, $\mathrm{CO}_{2}$ assimilation and root hydraulic conductivity (Vélez et al., 2012; Semida et al., 2020).
The results from the water applications based on soil moisture agree with those reported by López et al. (2011), who argued that applications of irrigation regimes based on evapotranspiration and soil moisture generate greater water use efficiency, which is much greater when supplying up to $80 \%$ of the total water needs of the crop, achieving higher production with a reduced water volume and providing optimal costbenefit ratios for large-scale irrigation systems (Geries et al., 2020).

\section{Growth of the polar diameter and equatorial diameter}

The production and efficiency of the proposed system is better illustrated by the crop growth variables. Figure 1A shows growth in terms of the polar diameter, and figure $1 \mathrm{~B}$ shows the equatorial diameter of the bulbs. For the polar diameter, significant statistical differences were found between the treatments with a 95\% confidence level at weeks 2, 3, and 10 . The growth of the polar diameter decreased from week 1 of the evaluation to week 8 , with an increase in the equatorial diameter, especially when the plants entered the bulbous stage. On the other hand, from week 8 to week 11, there was new growth, accumulating the largest amount of photoassimilates, with increases in the polar and equatorial diameters (Estrada-Prado et al., 2015).

The positive response in the polar and equatorial diameters in 100\% Evt (Fig. 1A) was related to the applied water regime, which provided enough moisture in the soil for optimal cultivar production (Kumar et

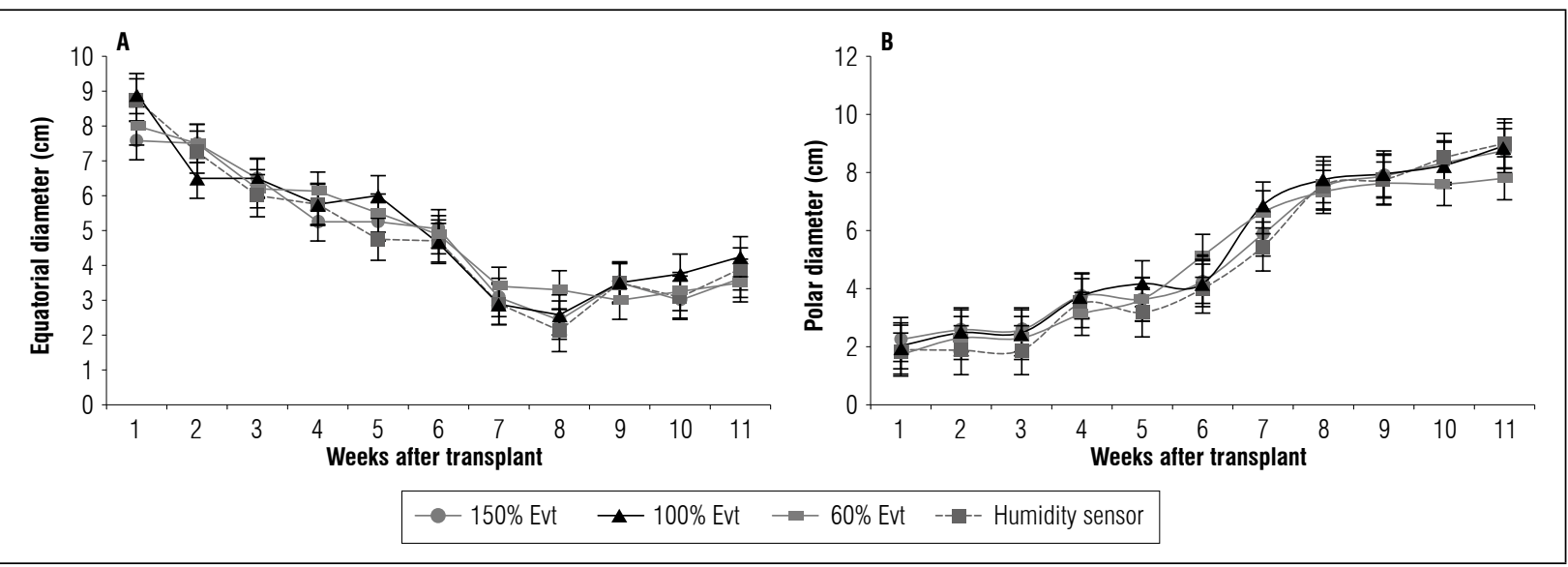

Figure 1. A, development of polar diameter in onion bulbs subjected to four irrigation regimes; B, development of equatorial diameter in onion bulbs subjected to four irrigation regimes. Evt: evapotranspiration. 
al., 2007). In $60 \%$ Evt, which had a smaller polar diameter, the results agreed with de Santa (2004), who suggested that a reduction in a water regime decreases bulb growth because it is not possible to carry out the processes of cell division as fast as with the required amount of available water, generating water stress. This indicates that not only fertilization is required for bulb development; without adequate water in the soil, a plant will decrease in quality (Patel and Rajput, 2008; Dai et al., 2020).

The results for the equatorial diameter had significant statistical differences $(P \leq 0.05)$ in week 5. Moisture sensors and 100\% Evt developed better, reaching average values of 8.92 and $9 \mathrm{~cm}$, higher than those found by Cargua, (2013), who reported equatorial diameter values of 7.42 and $7.20 \mathrm{~cm}$ per bulb for the Yellow granex variety, lower even than the diameters of $7.8 \mathrm{~cm}$ in $60 \%$ Evt.

Alvarez-Herrera et al. (2017) reported that the growth of bulb onions is sigmoidal, explaining the reduction of the polar diameter and increase of the equatorial diameter, with subsequent flattening related to the accumulation of photoassimilates during the bulbification stage. Kumar et al. (2007) stated that water regimes greater than the evapotranspiration normally generate an increase in the polar diameter of bulb onions, even when the applications reach 150\% Evt. Additionally, stimulation of the soil temperature, which increases root length, will increase the availability of nutrients in solution for fulfillment of the basic metabolic processes, with a respective increase in the diameter and total weight of the plant (de Freitas et al., 2020).
The results agreed with those found by Castro et al. (2009), who stated that, in the bulbification phase, the equatorial diameter increases up to $65 \%$ because of storage of photosynthesis products. The equatorial diameter value reported by these authors was $6.6 \mathrm{~cm}$, close to the diameters found in $60 \%$ Evt, which, in both cases, were observed with water stress.

\section{Leaf and root growth}

Significant statistical differences were found with a $P \leq 0.005$ in evaluation weeks $2,4,7$, and 8 for leaf length and in week 11 for root length. For leaf length (Fig. 2a), the value was almost constant from week 3 to 11 , with the highest value in $100 \%$ Evt $(60.5 \mathrm{~cm})$. Treatments $150 \%$ Evt, moisture sensors and $60 \%$ Evt had lower values; 1 had the lowest value at $56.2 \mathrm{~cm}$. The root length variable (Fig. $2 \mathrm{~B}$ ) had its highest value in $100 \%$ Evt, with a value of $14 \mathrm{~cm}$. Treatments $150 \%$ Evt and moisture sensors had the lowest value at $12.5 \mathrm{~cm}$.

The growth of the leaves and roots was closely related to the scarce water supply, as seen in $60 \%$ Evt, which triggered a reduction in plant growth. An adequate supply of water in regimes that provide 80 to $100 \%$ Evt can impart adequate root and leaf growth values (Shao et al., 2008). Using smaller amounts of water, as with the moisture sensors, does not guarantee adequate root development, instead generating shorter and thicker roots and limiting the necessary amount of absorbed water because of a smaller surface area (Alvarez-Herrera et al. 2017; Wakchaure et al., 2020).

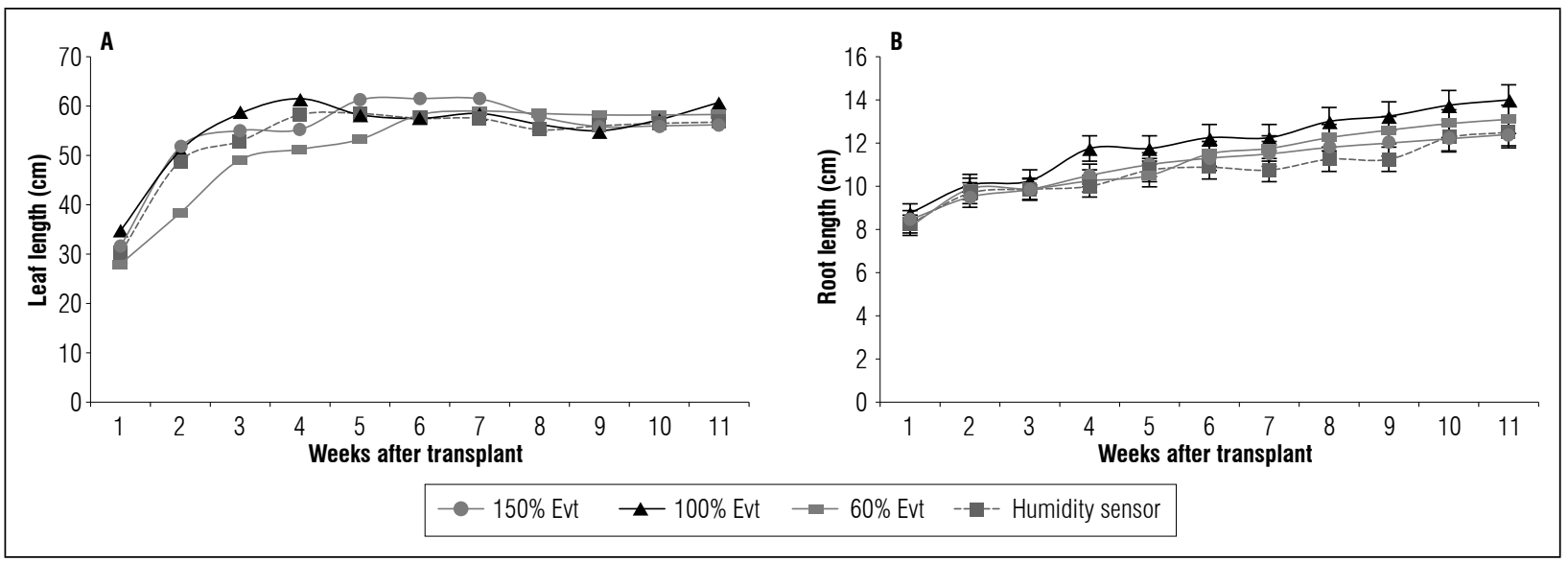

Figure 2. A, bulb onion leaf length under four irrigation regimes; B, bulb onion root length under four irrigation regimes. Evt: evapotranspiration. 
The treatment $150 \%$ Evt had the shortest root length $(8.13 \mathrm{~cm})$ because, when the soil has moisture saturation, gases such as $\mathrm{O}_{2}$ and $\mathrm{CO}_{2}$ diffuse more slowly, making them inaccessible to the roots. As a result, the lack of oxygen decreases ATP production, causing a reduction in root metabolism and in plant nutrition (Sauter, 2013; Taiz et al., 2015; Alvarez-Herrera et al., 2017; Piri and Naserin, 2020).

The treatment 150\% Evt also had the lowest leaf length value because the high moisture saturation in the soil decreased the oxygen and caused anoxia in the soil, producing a greater amount of aminocyclopropane carboxylic acid (ACC) that was transported from the roots to the aerial part, where it becomes ethylene, decreasing growth and foliar abscission (Irfan et al., 2010; Steen and Benkeblia, 2013; Sarkar et al., 2019).

\section{Relative chlorophyll index (RCI) or SPAD units}

In the first weeks after transplant, all treatments had a similar trend until week 4 . In week 5 , there was a high RCI value. The higher values were seen with the moisture sensors and 60\% Evt, 140.55 and 132.9, respectively. The treatments $150 \%$ Evt and $100 \%$ Evt presented lower values, 103 and 108.13, respectively. The values decreased again in week 6 , increased in week 7 , decreased in week 9 , and increased again until week 11, when the harvest occurred. The treatments moisture sensor and $60 \%$ Evt presented higher values, followed by $150 \%$ Evt and $100 \%$ Evt, which presented a similar value (107). There were only significant differences in weeks 3 ,

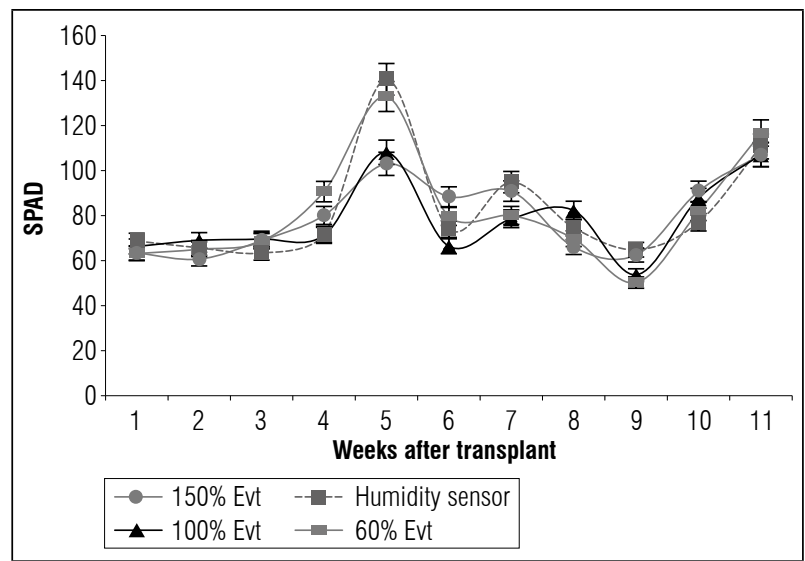

Figure 3. SPAD units in bulb onions under four irrigation regimes. Evt: evapotranspiration.
4 , and 5 according to Tukey's multiple comparison test $(P \leq 0.05)$ (Fig. 3$)$.

In the first four weeks, the SPAD readings remained almost constant. In week 5 , there was considerable growth, which could have been due to targeting photoassimilates (Bonza-Espinoza et al., 2016). Sampling point 5 had the highest SPAD unit peak, related to the physiological reaction of the plants to the application of amino acids (AAS), supplied to counteract the effects of low temperatures in that week, which provided significant amounts of $\mathrm{N}$ necessary for the synthesis of chlorophyll. The high concentration of foliar nitrogen in the plants, which is directly reflected to SPAD unit values, meant a higher value, especially in treatments that had lower amounts of water (Castillo and Ligarreto, 2010).

The chlorophyll results agreed with those obtained by (Palencia et al., 2016), especially in the later weeks of the analysis, where the SPAD units measured in old leaves had similar values, in the range of 60 and $80 \mathrm{~s}$. The significant increase in the later weeks was evidence of the fertilization response of bulb filling, which was carried out in week 9 , with the physiological response detected in weeks 10 and 11 (Arjona et al., 2004; Medellín et al., 2011).

\section{Stomatal conductance}

There were significant statistical differences with $P \leq 0.05$ at sampling points 5, 9, and 11 (Fig. 4).

Figure 4 shows the stomatal conductance, which increased and decreased over time in relation to

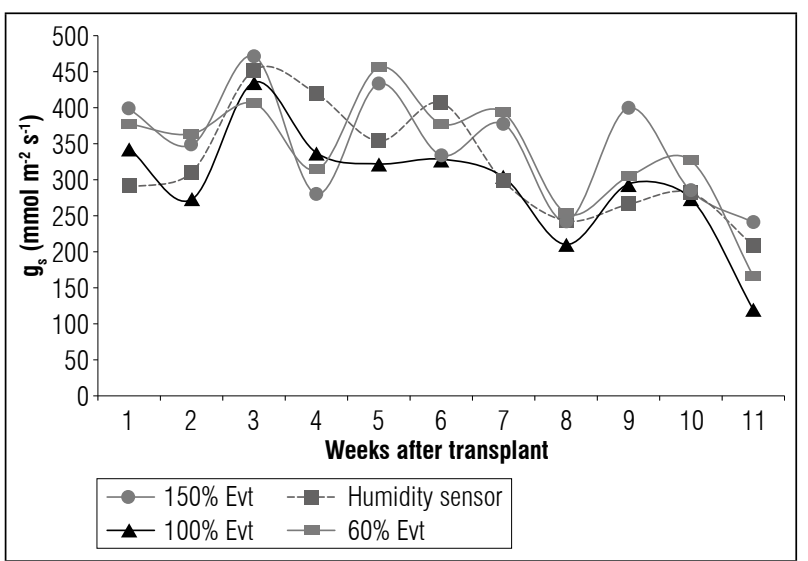

Figure 4. Stomatal conductance in bulb onions under four irrigation regimes. Evt: evapotranspiration. 
variations in the sodium concentrations in the soil because of the crop field salinity, especially on days where high temperatures resulted in dehydration of the first centimeters of the soil. Soil salinity generates stress in roots because of the synthesis of abscisic acid $(\mathrm{ABA})$ as an early response to physiological changes, such as the reduction of hydraulic conductivity and remote stomatal closure, generating direct blockage in photosynthesis because of the limited entry of $\mathrm{CO}_{2}$, a necessary substrate for the Calvin cycle (Jiménez et al., 2012; Quintana et al., 2016).

Coca et al. (2012) stated that sensitivity to saline stress in onions varies directly with the phenological stage and may be associated with other pathologies, which may include the conditions that lead to increased pink root incidence, directly affecting root growth, root thickness, and production, with a reduction in water potential, preventing the absorption of water by roots, and cellular reduction of the root apex and young leaves. This is more evident in root length because of a reduction in the capacity to uptake nutrients such as $\mathrm{K}^{+}$and $\mathrm{Ca}^{+2}$ (Semida et al., 2020).

The use of porometers or other devices for measuring stomatal conductance and water potential in onion bulbs is limited because anatomical structures on leaves are covered by a waxy layer or cuticle, stomata are sunken and guard cells lack starch and chloroplasts. The concentration of atmospheric $\mathrm{CO}_{2}$ and light intensity directly influence stomatal opening; the radiation that occurs in the Tundama Valley region contributes to above normal values. The use of measurement instruments may be limited, and values may be biased (Perez and Knox, 2014; Semida et al., 2020).

\section{CONCLUSIONS}

Determining the irrigation regime with the soil moisture sensors led to the use of a smaller amount of water and to a higher water yield in terms of IWUE, as compared to the irrigation regimes calculated with the Evt.

The $100 \%$ Evt regime saw the highest bulb onion production value.

Monitoring the relative chlorophyll index or SPAD units and stomatal conductance indicated that the irrigation regimes did not result in significant differences because of the influence of different physiological and climatic variables that directly affect the validity of data recorded by devices.

Expand studies on the edaphoclimatic variables of the study area are needed to provide technical measures for the efficient use of irrigation water.

\section{ACKNOWLEDGMENTS}

The authors thank MinCiencias for funding this research through convocatoria $N^{\circ} 733$ de 2015. Result of the degree work entitled: Efficient use of water for irrigation in bulb onion. Irrigation District of Alto Chicamocha. A comprehensive proposal from Agro-Sciences.

Conflict of interests: The manuscript was prepared and reviewed with the participation of the authors, who declare that there exists no conflict of interest that puts at risk the validity of the presented results.

\section{BIBLIOGRAPHIC REFERENCES}

Alvarez-Herrera, J.G., O.H. Alvarado-Sanabria, and F.A. Suesca-Ochoa. 2017. Efecto de diferentes láminas de riego en el crecimiento y desarrollo de cebolla de bulbo (Allium cepa L.). Rev. Colomb. Cienc. Hortic. 11(2), 359-367. Doi: 10.17584/rcch.2017v11i2.7345

Arjona, H., J.E. Herrera, J.A. Gómez, and J. Ospina. 2004. Evaluación de la aplicación de urea, melaza y aminoácidos sobre el crecimiento y rendimiento de la cebolla de bulbo (Allium cepa L. Grupo cepa) híbrido yellow granex, en condiciones de la Sabana de Bogotá. Agron. Colomb. 22(2), 177-184.

Assuero, S.G., J. Rattin, J. Saluzzo, G. Sasso, and J.A. Tognetti. 2007. Observaciones sobre la producción y conservación de cebolla en el sudeste de Buenos Aires en relación con la disponibilidad hídrica. Rev. Fac. Agron. 106(2), 109-118.

Bolaños, M.M., J.S. Gutiérrez, and G.H. Rueda. 2017. Manejo eficiente de agua y suelo para reducir riesgo agroclimático en un cultivo de cebolla. Suelos Ecuat. 47(1-2), 93-98.

Bonet, C., I. Acea, O. Brown, M. Hernández, and C. Duarte. 2010. Coeficientes de cultivo para la programación del riego de la piña. Rev. Cienc. Téc. Agropec. 19(3), 23-27.

Bonza-Espinoza, M., E. Pinzón-Sandoval, and J. Álvarez-Herrera. 2016. Efecto del nitrato de potasio y la sacarosa sobre el rendimiento de plantas de cebolla (Allium cepa L.). Temas Agrarios 21(2), 40-50. Doi: 10.21897/rta.v21i2.900 
Caicedo, O., C. Balmaseda, and J. Proaño. 2015. Programación del riego del banano (Musa paradisiaca) en finca San José 2, Los Ríos, Ecuador. Rev. Cienc. Téc. Agropec. 24(2), 18-22.

Cargua, Y.M. 2013. Respuesta de la cebolla perla (Allium cepa L.) a cuatro densidades de siembra y dos láminas de riego. Undergraduate thesis. Universidad Central del Ecuador, Ascázubi, Ecuador.

Castillo, Á.R. and G.A. Ligarreto. 2010. Relación entre nitrógeno foliar y el contenido de clorofila, en maíz asociado con pastos en el Piedemonte Llanero colombiano. Cienc. Tecnol. Agropec. 11(2), 122-128. Doi: 10.21930/rcta.vol11_num2_art:202

Castro, H., G. Cely. and S. Vázquez. 2009. Criterios técnicos para un manejo eficiente de lal riego en cebolla de bulbo. Distrito de riego del alto Chicamocha- Boyacá. Editorial Uptc, Tunja, Colombia.

Channagoudra, R., A. Prabhudeva, and A. Kamble. 2009. Response of onion (Allium cepa L.) to different levels of irrigation and sulphur in alfisols of northern transitional tract of Karnataka. Asian J. Hortic. 4(1), 152-155.

Coca, A., C.E. Carranza, D. Miranda, and M.H. Rodríguez. 2012. Efecto del $\mathrm{NaCl}$ sobre los parámetros de crecimiento, rendimiento y calidad de la cebolla de bulbo (Allium cepa L.) bajo condiciones controladas. Rev. Colomb. Cienc. Hortic. 6(2), 196-212. Doi: 10.17584/ rcch.2012v6i2.1977

Dai, C., X. Oin, W. Lu, and Y. Huang. 2020. Assessing adaptation measures on agricultural water productivity under climate change: A case study of Huai River Basin, China. Sci. Total Environ. 721, 137777. Doi: 10.1016/j.scitotenv.2020.137777

de Freitas, M., T.S. Silva, J.B. dos Santos, G.D.O.P. Carneiro, L.T.R.T. Reginaldo, J.N. Bandeira, M.S. dos Santos, Q.S. Pavão, M.Z. de Negreiros, and D.V. Silva. 2020. Soil water availability alter the weed community and its interference on onion crops. Sci. Hortic. 272, 109573. Doi: 10.1016/j.scienta.2020.109573

de Santa, F.M., A. Dominguez-Padilla, and R. Lopez. 2004. Production and quality of the onion crop (Allium cepa L.) cultivated under controlled deficit irrigation conditions in a semi-arid climate. Agric. Water Manage. 68(1), 77-89. Doi: 10.1016/j.agwat.2004.02.011

Enciso, J., B. Wiedenfeld, J. Jifon, and S. Nelson. 2009. Onion yield and quality response to two irrigation scheduling strategies. Sci. Hortic. 120(3), 301-305. Doi: 10.1016/j.scienta.2008.11.004

Estrada-Prado, W., E. Lescay-Batista, A. Álvarez-Fonseca, and Y.C. Maceo-Ramos. 2015. Niveles de humedad en el suelo en la producción de bulbos de cebolla. Agron. Mesoam. 26(1), 112-117. Doi: 10.15517/ am.v26i1.16934

Geries, L., T. El-Shahawy, and E. Moursi. 2020. Cut-off irrigation as an effective tool to increase water-use efficiency, enhance productivity, quality and storability of some onion cultivars. Agric. Water Manage. 244, 106589. Doi: 10.1016/j.agwat.2020.106589

Gómez, J.J.C., R.B. Muñoz, and M.L.H. Rodríguez. 2015. Calidad del agua para riego en la agricultura protegida en Tlaxcala. Ingeniería 19(1), 39-50.

Haller, H. and A. Jonsson. 2020. Growing food in polluted soils: A review of risks and opportunities associated with combined phytoremediation and food production (CPFP). Chemosphere 254, 126826. Doi: 10.1016/j.chemosphere.2020.126826

Infostat. 2020. Software estadístico. In: www.infostat. com.ar; consulted: August, 2020.

Irfan, M., S. Hayat, Q. Hayat, S. Afroz, and A. Ahmad. 2010. Physiological and biochemical changes in plants under waterlogging. Protoplasma 241(1-4), 3-17. Doi: 10.1007/s00709-009-0098-8

Jiménez, J.C., L.P. Moreno, and S. Magnitskiy. 2012. Respuesta de las plantas a estrés por inundación: una revisión. Rev. Colomb. Cienc. Hortic. 6(1), 96-109. Doi: 10.17584/rcch.2012v6i1.1287

Kijne, J.W., T.P. Tuong, J. Bennett, B. Bouman, and T. Oweis. 2003. Ensuring food security via improvement in crop water productivity. Challenge Program on water and Food, Battaramulla, Sri Lanka.

Kumar, S., M. Imtiyaz, A. Kumar, and R. Singh. 2007. Response of onion (Allium cepa L.) to different levels of irrigation water. Agric. Water Manage. 89(1-2), 161166. Doi: 10.1016/j.agwat.2007.01.003

Liu, M., X. Xu, Y. Jiang, O. Huang, Z. Huo, L. Liu, and G. Huang. 2020. Responses of crop growth and water productivity to climate change and agricultural water-saving in arid region. Sci. Total Environ. 703, 134621. Doi: 10.1016/j.scitotenv.2019.134621

López, T., G. Cid, F. González, J. Herrera, and Y. Chaterlán. 2011. Modelación de la eficiencia del uso del agua en maíz y frijol en diferentes condiciones de suelos y disponibilidad hídrica. Rev. Ing. Agríc. 1(2), 41-47.

Mai, T., S. Mushtaq, A. Loch, K. Reardon-Smith, and D.A. An-Vo. 2019. A systems thinking approach to water trade: Finding leverage for sustainable development. Land Use Policy 82, 595-608. Doi: 10.1016/j. landusepol.2019.01.004

Medellín, L.A.C., A.M.B. Rozo, and M.M.P. Trujillo. 2011. Ensayo preliminar sobre la utilización de un medidor portátil de clorofila para estimar el nitrógeno foliar en orégano (Origanum vulgare L.). Rev. Fac. Cienc. Básicas 7(2), 150-165.

Minhas, P., T.B. Ramos, A. Ben-Gal, and L.S. Pereira. 2020. Coping with salinity in irrigated agriculture: Crop evapotranspiration and water management issues. Agric. Water Manage. 227, 105832. Doi: 10.1016/j. agwat.2019.105832

Palencia, P., F. Martinez, M. Burducea, J.A. Oliveira, and I. Giralde. 2016. Efectos del enriquecimiento con selenio en SPAD, calidad de la fruta y parámetros de 
crecimiento de plantas de fresa en un sistema de cultivo sin suelo. Rev. Bras. Frutic. 38(1), 202-212. Doi: 10.1590/0100-2945-294/14

Patel, N. and T. Rajput. 2008. Dynamics and modeling of soil water under subsurface drip irrigated onion. Agric. Water Manage. 95(12), 1335-1349. Doi: 10.1016/j. agwat.2008.06.002

Perez, M. and J. Knox. 2014. Water relations and irrigation requirements of onion (Allium cepa L.): A review of yield and quality impacts. Exp. Agric. 51(2), 210-231. Doi: 10.1017/S0014479714000234

Piri, H. and A. Naserin. 2020. Effect of different levels of water, applied nitrogen and irrigation methods on yield, yield components and IWUE of onion. Sci. Hortic. 268, 109361. Doi. 10.1016/j.scienta.2020.109361

Quintana, W.A., E.H. Pinzón, and D.F. Torres. 2016. Evaluación del crecimiento de fríjol (Phaseolus vulgaris L.) cv. Ica Cerinza, bajo estrés salino. Rev. U.D.C.A Act. \& Div. Cient. 19(1), 87-95. Doi: 10.31910/rudca.v19. n1.2016.113

Rattin, J.E., S.G. Assuero, G.O. Sasso, and J.A. Tognetti. 2011. Accelerated storage losses in onion subjected to water deficit during bulb filling. Sci. Hortic. 130(1), 25-31. Doi: 10.1016/j.scienta.2011.06.026

Ríos, J.L., M. Torres, J. Ruiz, and M.A. Torres. 2016. Eficiencia y productividad del agua de riego en trigo (Triticum vulgare) de Ensenada y Valle de Mexicali, Baja California, México. Acta Univer. 26(1), 20-29. Doi: 10.15174/ au. 2016.825

Ríos-Flores, J.L., M. Torres-Moreno, J. Ruiz-Torres, M.A. Torres-Moreno, and J.E. Cantú-Brito. 2015. Evaluación productiva, económica y social del agua de riego de durazno (Prunus persica L. Batsch) en Zacatecas (México). Avan. Investig. Agropecu. 19(2), 97-110.

Sánchez, R.A., M. Servin, H. Gutiérrez, and A. Serna. 2017. Eficiencia en el uso del agua de variedades de alfalfa (Medicago sativa L.) con sistema de riego subsuperficial. Rev. Mex. Cienc. Pec. 8(4), 429-435. Doi: 10.22319/rmcp.v8i4.4255

Sarkar, M.D., A.H.M. Solaiman, M.S. Jahan, R.N. Rojoni, K. Kabir, and M. Hasanuzzaman. 2019. Soil parameters, onion growth, physiology, biochemical and mineral nutrient composition in response to colored polythene film mulches. Ann. Agric. Sci. 64(1), 63-70. Doi: 10.1016/j.aoas.2019.05.003

Sauter, M. 2013. Root responses to flooding. Curr. Opin. Plant Biol. 16(3), 282-286. Doi: 10.1016/j. pbi.2013.03.013

Semida, W.M., A. Abdelkhalik, M.O. Rady, R.A. Marey, and T.A. Abd El-Mageed. 2020. Exogenously applied proline enhances growth and productivity of drought stressed onion by improving photosynthetic efficiency, water use efficiency and up-regulating osmoprotectants. Sci. Hortic. 272, 109580. Doi: 10.1016/j. scienta.2020.109580

Shao, H.-B., L.-Y. Chu, C.A. Jaleel, and C.-X. Zhao. 2008. Water-deficit stress-induced anatomical changes in higher plants. CR Biol. 331(3), 215-225. Doi: 10.1016/j. crvi.2008.01.002

Steen, S. and N. Benkeblia. 2013. Variation of reducing and total sugars during growth of onion tissues. Acta Hortic. 1047, 51-55. 10.17660/ActaHortic.2014.1047.3

Taiz, L., E. Zeiger, I.M. Møller, and A. Murphy. 2015. Plant physiology and development. $6^{\text {th }}$ ed. Sinauer Associates, Sunderland, CT.

Vélez, J.E., J.G. Álvarez-Herrera, and O.H. Alvarado-Sanabria. 2012. El estrés hídrico en cítricos (Citrus spp.): Una revisión. Orinoquia 16(2), 32-39.

Vergel, M., J.J. Martínez, and S.L. Zafra. 2016. Cultivo de cebolla (Allium cepa L.) en la provincia de Ocaña: factores asociados a la productividad y el rendimiento. Rev. Colomb. Cienc. Hortic. 10(2), 333-344. Doi: 10.17584/ rcch.2016v10i2.5070

Wakchaure, G., P. Minhas, K.K. Meena, S. Kumar, and J. Rane. 2020. Effect of plant growth regulators and deficit irrigation on canopy traits, yield, water productivity and fruit quality of eggplant (Solanum melongena L.) grown in the water scarce environment. J. Env. Manage. 262, 110320. Doi: 10.1016/j.jenvman.2020.110320

Wakchaure, G., P. Minhas, K.K. Meena, N.P. Singh, P.M. Hegade, and A.M. Sorty. 2018. Growth, bulb yield, water productivity and quality of onion (Allium cepa L.) as affected by deficit irrigation regimes and exogenous application of plant bio-regulators. Agric. Water Manage. 199, 1-10. Doi: 10.1016/j.agwat.2017.11.026 